\title{
CDK4/6 Inhibitor G1T38
}

National Cancer Institute

\section{Source}

National Cancer Institute. CDK4/6 Inhibitor G1T38. NCI Thesaurus. Code C138165.

An orally bioavailable inhibitor of cyclin-dependent kinase (CDK) types 4 (CDK4) and 6 (CDK6), with potential antineoplastic activity. Upon administration, CDK4/6 inhibitor G1T38 selectively inhibits CDK4 and CDK6, which inhibits the phosphorylation of retinoblastoma protein $(\mathrm{Rb})$ early in the G1 phase, prevents CDK-mediated G1-S phase transition and leads to cell cycle arrest. This suppresses DNA replication and decreases tumor cell proliferation. CDK4 and 6 are serine/threonine kinases that are upregulated in many tumor cell types and play a key role in the regulation of both cell cycle progression from the G1-phase into the S-phase and tumor cell proliferation. 